\title{
Interactive web site and app for early magnetic resonance education
}

\author{
Hanson, Lars G.
}

\section{Published in:}

Physica Medica

Link to article, DOI:

10.1016/j.ejmp.2016.07.556

Publication date:

2016

Document Version

Peer reviewed version

Link back to DTU Orbit

Citation (APA):

Hanson, L. G. (2016). Interactive web site and app for early magnetic resonance education. Physica Medica, 32(Supplement 3), 258. https://doi.org/10.1016/j.ejmp.2016.07.556

\section{General rights}

Copyright and moral rights for the publications made accessible in the public portal are retained by the authors and/or other copyright owners and it is a condition of accessing publications that users recognise and abide by the legal requirements associated with these rights.

- Users may download and print one copy of any publication from the public portal for the purpose of private study or research.

- You may not further distribute the material or use it for any profit-making activity or commercial gain

- You may freely distribute the URL identifying the publication in the public portal

If you believe that this document breaches copyright please contact us providing details, and we will remove access to the work immediately and investigate your claim 


\section{TITLE: 'INTERACTIVE WEB SITE AND APP FOR EARLY MAGNETIC RESONANCE EDUCATION’}

Lars G. Hanson ${ }^{1,2}$

${ }^{1}$ Danish Research Centre for MR, Copenhagen University Hospital Hvidovre, Denmark.

${ }^{2}$ Center for Magnetic Resonance, DTU Elektro, Technical University of Denmark, Lyngby, Denmark

\section{Introduction}

Teaching and understanding basic Magnetic Resonance (MR) is a challenge. This is clear from the educational literature that often repeats misinterpretations of quantum mechanics reminiscent of its earliest formulations (see www.drcmr.dk/MR that also links to the developed software). Modern quantum formulations of MR are much closer to classical descriptions than to typical quantum inspired myths frequent in literature. This opens for intuitive educational computer simulation using modern web technologies offering excellent interactive possibilities for experimentation.

\section{Purpose}

An educational web page and a corresponding free Android app, CompassMR, were developed for teaching of basic MR. They simulate Compass Magnetic Resonance that is easy to understand by all, and serves as an excellent starting point for introducing precession, nutation, FIDs and spectra, that are also simulated.

\section{Materials and Methods}

The web page was developed in JavaScript/HTML5 which is increasingly supported by modern browsers. A corresponding Android app was made using the PhoneGap web service that also offers iPhone and Windows phone support (but due to cost, currently no app is offered for these).

\section{Results}

The web page works well, e.g. in recent Chrome and Firefox browsers that supports HTML5. Soon after release, the corresponding app was running on more than 60 devices worldwide, and got top ratings.

\section{Conclusion}

Modern web technologies are suited for designing much needed educational simulation tools for MR.

\section{DISCLOSURE}

Nothing to disclose. 